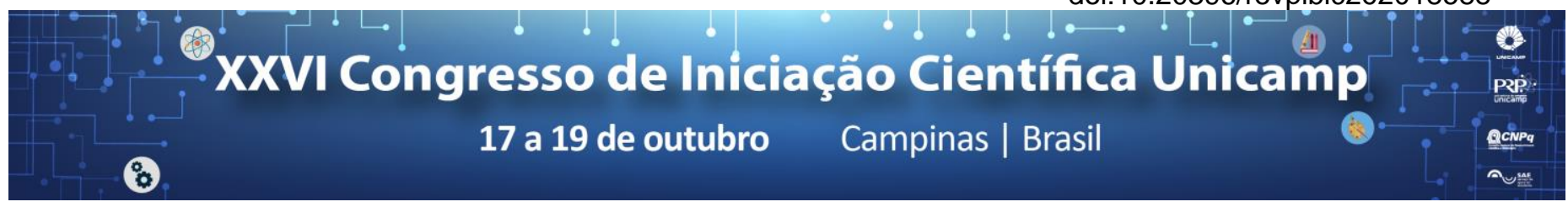

\title{
Environmental Criteria for Improving Dams Safety
}

\author{
Heloísa Bonatti ${ }^{\star}$, Laura Maria Canno Ferreira Fais.
}

\begin{abstract}
In view of the magnitude of a dam, the damage caused by some failure or rupture causes a great impact, which can result in socioeconomic and environmental losses, and also in loss of human lives. In Brazil, the law $n$ ‥ 12,334 was approved in 2010, which establishes the National Dams Security Policy and the National Information System on Dam Safety - SNISB, in order to monitor and guarantee the safety of dams. In addition to legislation, it is essential to have tools that assist in the evaluation of the conditions of the structures, and that allow the owner, responsible engineers and oversight agencies to make decisions, in order to avoid or at least minimize the occurrence of failures. One of the tools that can be used is the Safety Index of Dams (ISB), proposed by Zuffo (2005) and modified by Aguiar (2014). The ISB allows a global view of the safety status of the dam, being a useful tool of easy application. However, the ISB was determined considering only technological (or engineering) criteria. Thus, this research aims to propose criteria related to environmental factors that must be considered to evaluate the safety of a dam.
\end{abstract}

\section{Key words:}

Dams Safety Index (ISB), Dam Safety, Environmental Criteria.

\section{Introduction}

Brazil's current dependence on hydroelectric power and the water supply problems that occur during dry seanson make the construction of dams and reservoirs essential. There are 22,920 dams (ANA, 2016) and 1,332 hydroelectric plants (ANEEL, 2018) registered in Brazil today. Like any engineering work the construction and operation of these structures can have a high associated risk and cause environmental impacts.

The Ministry of National Integration created the Dams Safety Manual in 2002 to assist in the construction and rehabilitation of dams. In 2010, the Law n 12,334 established the National Dams Security Policy - PNSB and the National Dams Safety Information System SNISB in order to record information and ensure the safety of dams intended for accumulation of water for any use.

Zuffo (2005) developed the Dams Safety Index (ISB), to assess and monitor the safety conditions of a dams, serving as an auxiliary tool in decisions, Aguiar (2014) modified the index with the purpose of adhere to the ISB the criteria of the current Brazilian legislation. However, the author considered only technological criteria, linked to engineering, without considering the effects on safety caused by environmental factors. Therefore, it is important to elaborate environmental criteria for the Environmental Index of Dams Safety (ISBA).

\section{Results and Discussion}

The environmental criteria that should be considered when analyzing the safety of a dam were elaborated from the literature and Brazilian legislation. The criteria of the Brazilian legislation that analyze the associated potential damage are of extreme importance and will be considered in the Environmental Index of Dam Safety.

The climatic characteristics should also be considered, since rainfall and flood represent the main causes of failures in dams in Europe. Large dams increase the incidence of extreme rainfall in their region after their construction, so it is important to routinely assess the rainfall level to avoid unexpected floods that cause structural damage and accidents (Hossain, 2010). Global warming causes increased rainfall at high latitudes and lower rainfall at low latitudes, which alters the environmental conditions that the dams were built, so monitoring is required for the implementation of control measures. Changes in land use in the region also lead to changes in river flows that lead to changes in flood regimes (ICOLD, 2016).

Monitoring of water quality is necessary to prevent harmful changes from occurring. As, for example, the increase of nutrients which allows the occurrence of eutrophication and puts the safety of dams at risk by the increase of vegetation and debris. Also the increase of chemical substances that act as a leaching agent and can lead percolation paths, unacceptable drainage flows and neutral pressures (MIN,2002).

\section{Conclusions}

Both in Brazil and in the rest of the world, the dams are aging, which reinforces the need for care related to their safety. In order to avoid failures and accidents, the safety criteria and the legislation must be implemented already in the project phase, later during its construction and finally, must be continuously monitored during the operation. For a more effective evaluation, it is necessary to consider environmental criteria, since this significantly affects on the safety of the dams. Thus, the Environmental Dams Safety Index (ISBA) was proposed, composed of criteria that consider the environmental factors that put the safety of dams at risk.

AGUIAR, D. P. de O. Contribuição ao Índice de Segurança de Barragem - ISB. Thesis, Master's. UNICAMP, Campinas-SP, 2014.

BRASIL, ANA. Relatório de Segurança de Barragens - 2016. Available in:

<http://www2.ana.gov.br/> Access in February 2018

BRASIL, ANEEL. Matriz de Energia Elétrica: BIG. 2018. Available in:

<http://www2.aneel.gov.br/>. Access in July 2018

BRASIL. Lei Federal no 12.334/ 2010. Available in:

<http://www.planalto.gov.br/>. Access in March 2017

HOSSAIN, F. Relationship Large Dams and the Alteration in Extreme

Precipitation. Hazards Review, Vol. 11, No. 3, August 2010.

ICOLD. Global Climate Change, Dams, Reservoirs, and Related Water Resources. Vol. 12, Final, November 2016.

MIN. Manual de Segurança de Barragens, Brasília, DF, 2002.

ZUFFO, M. S. R. Metodologia para Avaliação da Segurança de Barragens. UNICAMP, Campinas - SP, Thesis, Master's, 2005. 